ISSN 1392-3196 / e-ISSN 2335-8947

Zemdirbyste-Agriculture, vol. 106, No. 4 (2019), p. 337-344

DOI 10.13080/z-a.2019.106.043

\title{
Genetic structure and identification of molecular markers associated with agrobiological traits in Capsicum annuum accessions
}

\author{
Hamid HATAMI MALEKI ${ }^{1}$, Reza DARVISHZADEH ${ }^{2}$, Mohsen SALEHIAN ${ }^{2}$, \\ Ghahraman BAGHERI ${ }^{3}$, Bahman ZAHEDI $^{3}$ \\ ${ }^{1}$ University of Maragheh, Faculty of Agriculture \\ Maragheh, I. R. Iran \\ E-mail: hatamimaleki@yahoo.com \\ ${ }^{2}$ Urmia University, Faculty of Agriculture \\ Urmia, I. R. Iran \\ ${ }^{3}$ Lorestan University, Faculty of Agriculture \\ Korram Abad, I. R. Iran
}

\begin{abstract}
Sweet pepper (Capsicum annuum L.) is considered as the most important vegetable crop worldwide. Association mapping based on linkage disequilibrium is a capable tool to identify genes controlling plant agrobiological characteristics. In this study, an association panel consisting of 29 indigenous sweet pepper accessions were collected from several geographical regions of Iran. The panel was evaluated phenotypically for sixteen fruit as well as plant architecture traits across two locations under field conditions. In molecular experiment, 10 inter simple sequence repeat (ISSR) markers were used for genomic fingerprinting of accessions. Results revealed abundant phenotypic variations within this germplasm and a total of 65 markers ranging from 3 to 10 per primer were identified in all accessions. Model-based structure analysis revealed two subpopulations. Out of 29 native sweet pepper accessions studied, $93.1 \%$ belonged to one of the two identified subpopulations and $6.9 \%$ showed mixed structure. A total of 17 marker-trait associations were detected based on a mixed linear model, of which one (UBC825-1) was found as a common marker for some agrobiological characters. The favourable 17 marker loci can be utilized in plant architecture breeding programmes according to specific breeding objectives.
\end{abstract}

Key words: linkage disequilibrium, marker-trait association, mixed linear model, sweet pepper.

\section{Introduction}

Plant genetic resources, as a major component of agricultural biodiversity, play a key role in improving agricultural production and productivity and are important for coping with climate change (Hodgkin, Bordoni, 2012). So, collection, maintenance and characterization of genetic resources are vital for a given plant population. Pepper (Capsicum spp.) is an economically important vegetable crop belonging to Solanaceae family. It was introduced from the West Indies into Europe in 1493 following the first voyage of Christopher Columbus, after which they were rapidly distributed to Africa and Asia (Zhang et al., 2016). Species belonging to the genus Capsicum are diploid and have $2 \mathrm{n}=2 \mathrm{x}=24$ chromosomes, meanwhile some others have $2 n=2 x=26$ chromosomes (Pozzobon et al., 2005).
Hot and sweet peppers belong to domesticated C. annuum species (van Zonneveld et al., 2015). Sweet pepper (Capsicum annuum L.) is a self-pollinated plant with hanging or horizontal flowers which facilitate the placement of pollen on its stigma (Padilha, Barbieri, 2016). Iran with four climatic seasons has suitable conditions for pepper growing. According to FAO data, Iran with approximately 4000-hectare area of cultivated pepper is ranked as thirty-five among the countries leading in pepper production (Bagheri et al., 2017). Large scale genetic variability has been represented for domestic sweet pepper accessions collected from different geographical regions of Iran based on morphological and physiological characteristics (Bagheri et al., 2017).

Knowledge on genetic variability and population structure is crucial for germplasm management and

Please use the following format when citing the article:

Hatami Maleki H., Darvishzadeh R., Salehian M., Bagheri G., Zahedi B. 2019. Genetic structure and identification of molecular markers associated with agrobiological traits in Capsicum annuum accessions. Zemdirbyste-Agriculture, 106 (4): $337-344$. DOI $10.13080 /$ z-a.2019.106.043 
conservation. In addition, with emerging DNA markers and appropriate statistical procedures it is now possible to identify informative markers for marker assisted selection (MAS) by investigating correlations between patterns of phenotypic and molecular diversity. Identifying markers tightly linked with characters of interest is important for the successful deployment of DNA marker technology in breeding programs.

Inter-simple sequence repeats (ISSRs) have shown to be good markers for assessing the molecular genetic diversity. ISSR markers use short repeated sequences of DNA to amplify anonymous loci and do not require prior knowledge of the genome sequence (Kumar et al., 2014). The efficiency of ISSR markers in assessing the genetic diversity and classifying Capsicum spp., in particular C. annuum, was proven by several studies (Thul et al., 2011; Dias et al., 2013). In C. annuum quantitative trait loci (QTL) mapping activities have been mainly performed through bi-parental breeding populations such as $\mathrm{F}_{2}$-intercrosses (Ben Chaim et al., 2001; Lee et al., 2016) and recombinant inbred lines (Dwivedi et al., 2015). However, due to a few recombination events happening in these populations, the associated markers are not often tightly linked to the trait of interest (Myles et al., 2009). In this regard, association analysis or linkage disequilibrium (LD)-based mapping offers a good alternative approach for detecting markers tightly linked to the trait of interest in natural populations, germplasm collections and even genotypes routinely generated from breeding programs (Korte, Farlow, 2013; Verdeprado et al., 2018).

Although association studies and genomic selection have been practiced in $C$. annuum, there are a few reports about implementation of genomic regions containing repeated sequences like ISSR markers in this species. Examining linkage disequilibrium distribution across the $C$. annuum genome can help scientists to understand the consequences of selection throughout its breeding history (Nimmakayala et al., 2014).

In this study, for the first time the extent of linkage disequilibrium pattern and genetic structure of Iranian sweet pepper germplasm were elucidated, and then genomic regions associated with agrobiological traits were determined through a mixed linear model procedure.

\section{Materials and methods}

Collection and measurements of agrobiological traits. Seeds of 29 sweet pepper (Capsicum annuum L.) accessions were collected from several geographical regions of Iran (Table 1, Fig. 1). These regions with diverse climates are known as suitable regions for sweet pepper production. The accessions were evaluated for agrobiological traits in two separate lattice designs with three replications in 2013. Experimental designs were implemented at the research farm of Agricultural

Table 1. Code and origin of the studied sweet pepper accessions, membership percentage of each accession to constructed subgroups (Q-matrix)

\begin{tabular}{|c|c|c|c|c|c|}
\hline \multirow{2}{*}{ Code } & \multirow{2}{*}{ Region } & \multirow{2}{*}{ Province } & \multirow{2}{*}{$\begin{array}{l}\text { Group colour } \\
\text { in structure }\end{array}$} & \multicolumn{2}{|c|}{ Q-matrix } \\
\hline & & & & Q2 & Q1 \\
\hline G01 & Sabzevar & Razavi Khorasan & red & 0.148 & 0.852 \\
\hline G02 & Khorasan & Khorasan & red & 0.082 & 0.918 \\
\hline G03 & Urmia & West Azerbaijan & red & 0.123 & 0.877 \\
\hline G04 & Tabriz & East Azerbaijan & red & 0.13 & 0.87 \\
\hline G05 & Tafresh & Markazi & red & 0.046 & 0.954 \\
\hline G06 & Mahallat & Markazi & red & 0.06 & 0.94 \\
\hline G07 & Boroujerd & Lorestan & $\operatorname{mix}$ & 0.515 & 0.485 \\
\hline G08 & Shiraz & Fars & red & 0.316 & 0.684 \\
\hline G09 & Lordeghan 1 & Chaharmahal and Bakhtiari & red & 0.023 & 0.977 \\
\hline G10 & Boyerahmad & Kohgiluyeh and Boyer-Ahmad & red & 0.225 & 0.775 \\
\hline G11 & Chaharmahal & Chaharmahal and Bakhtiari & red & 0.072 & 0.928 \\
\hline G12 & Minab & Hormozgan & red & 0.038 & 0.962 \\
\hline G13 & Kurdistan 1 & Kurdistan & red & 0.035 & 0.965 \\
\hline G14 & Kurdistan2 & Kurdistan & red & 0.095 & 0.905 \\
\hline G15 & Kurdistan3 & Kurdistan & red & 0.071 & 0.929 \\
\hline G16 & Kashtiban-Urmia & West Azerbaijan & green & 0.78 & 0.22 \\
\hline G17 & Bojnourd & North Khorasan & $\operatorname{mix}$ & 0.618 & 0.382 \\
\hline G18 & Gharamalek & East Azerbaijan & green & 0.816 & 0.184 \\
\hline G19 & Bonab & East Azerbaijan & red & 0.151 & 0.849 \\
\hline $\mathrm{G} 20$ & Baneh & Kurdistan & green & 0.739 & 0.261 \\
\hline $\mathrm{G} 21$ & Joghatai & Razavi Khorasan & green & 0.967 & 0.033 \\
\hline $\mathrm{G} 22$ & Gachsaran & Kohgiluyeh and Boyer-Ahmad & green & 0.812 & 0.188 \\
\hline $\mathrm{G} 23$ & Bashghale-Urmia & West Azerbaijan & green & 0.868 & 0.132 \\
\hline $\mathrm{G} 24$ & Maragheh & East Azerbaijan & green & 0.915 & 0.085 \\
\hline $\mathrm{G} 25$ & Gharebagh-Urmia & West Azerbaijan & green & 0.699 & 0.301 \\
\hline G26 & Touyserkan & Hamedan & green & 0.976 & 0.024 \\
\hline $\mathrm{G} 27$ & Nakhjavan-Urmia & West Azerbaijan & green & 0.936 & 0.064 \\
\hline G28 & Ghijlar-Urmia & West Azerbaijan & green & 0.928 & 0.072 \\
\hline G29 & Urfa & Şanlıurfa, south-eastern Turkey & green & 0.912 & 0.088 \\
\hline
\end{tabular}




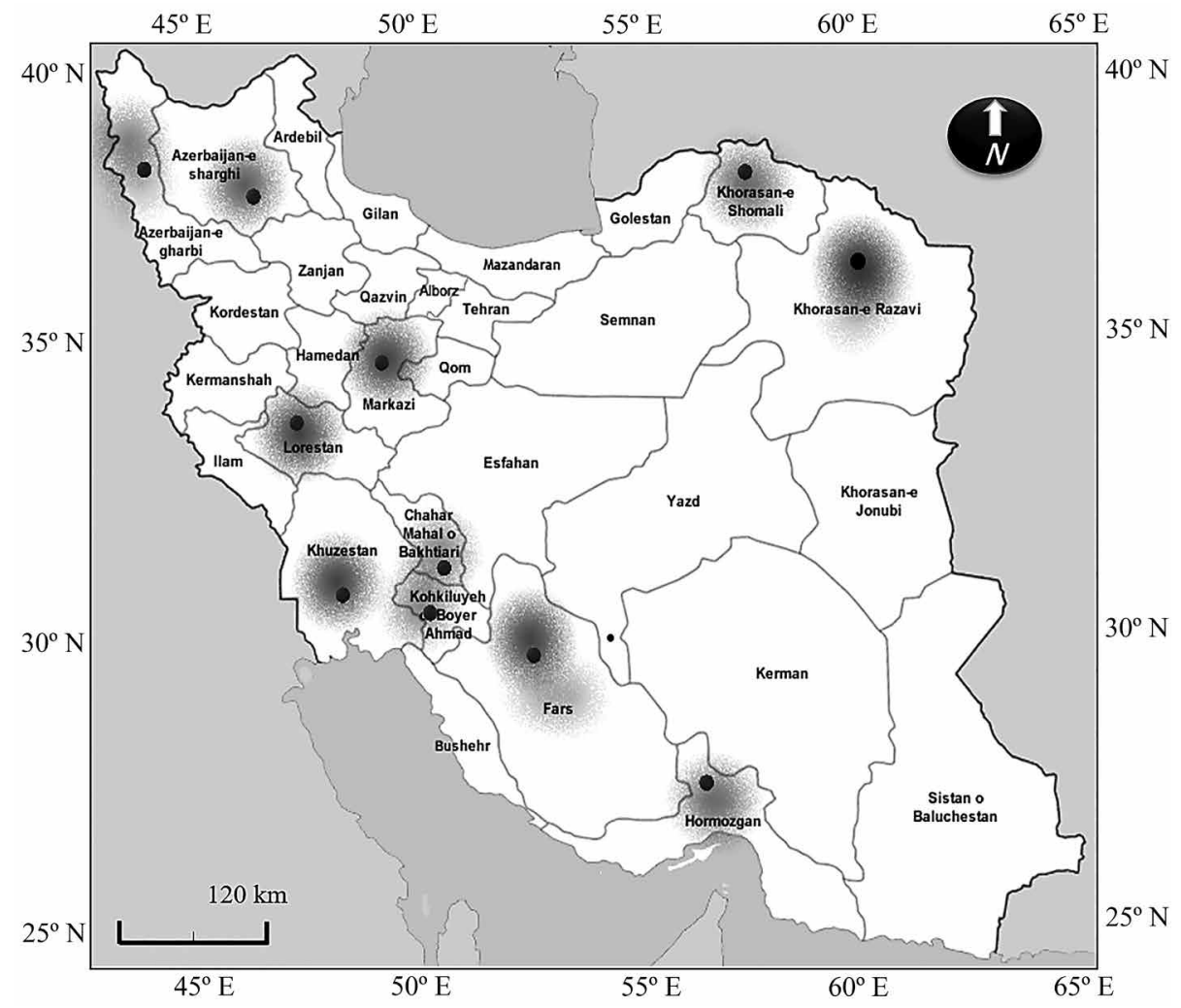

Figure 1. Geographic distribution of collected sweet pepper accessions in Iran

Research Center, West-Azerbaijan, Iran. Sixteen fruit and plant characters were measured according to the international Plant Genetic Resources Institute's (PGRI) descriptors for Capsicum.

The evaluated traits were fruit length $(\mathrm{cm})$, pericarp thickness $(\mathrm{mm})$, length of fruit tail $(\mathrm{cm})$, fruit diameter at the widest point $(\mathrm{cm})$, fresh weight of 10 fruits $(\mathrm{g})$, dry weight of 10 fruits $(\mathrm{g})$, yield $\left(\mathrm{kg} \mathrm{m}^{-2}\right)$, stem diameter $(\mathrm{mm})$, stem length $(\mathrm{cm})$, width of umbrella $(\mathrm{cm})$, plant height $(\mathrm{cm})$, length of inflorescence $(\mathrm{cm})$, anther length $(\mathrm{mm})$, number of primary branches, number of secondary branches and number of lateral branches.

Germplasm genotyping. Genomic DNA was extracted from the mixture of leaves of 15 plants per accession according to the method described by Devi et al. (2013). The concentrations of the DNA samples were determined by a spectrophotometer BioPhotometer 6131 (Eppendorf, Germany) at $260 \mathrm{~nm}$. The quality of the DNA was checked by running $1 \mu \mathrm{g}$ DNA on $0.8 \%$ $(\mathrm{w} / \mathrm{v})$ agarose gel in $0.5 \mathrm{X}$ TBE (Tris-borate-EDTA) buffer ( $45 \mathrm{mM}$ Tris base, $45 \mathrm{mM}$ boric acid, $1 \mathrm{mM}$ EDTA, pH 8.0).

In the present study, 10 ISSR primers out of 40 (Isshiki et al., 2008; dos Santos Araújo et al., 2016), producing repeatable and sharp bands on four accessions, were selected as testers for further fingerprinting analysis. Polymerase chain reaction was carried out using the method described by Thul et al. (2011). The amplification products were visualized on $1.8 \%(\mathrm{w} / \mathrm{v})$ ultrapure agarose Invitrogen (Thermo Fisher Scientific) with ethidium bromide $\left(1 \mu \mathrm{g} \mathrm{ml}^{-1}\right)$ and photographed using a gel documentation system Gel Logic 212 PRO (USA).
Statistical analysis. Experimental data was processed using statistical software $R$ ( $R$ Core Team, USA). In the ISSR molecular experiment, each gel was scored as 1 and 0 for the presence and absence of bands. Statistics such as total number of bands, polymorphic bands and percent of polymorphism were calculated for each ISSR primer. Population structure was analysed using a model-based Bayesian approach in the software Structure, version 2.3.4 (Pritchard et al., 2000). Five independent runs were performed, setting the number of sub populations $(\mathrm{K})$ from 1 to 10 , burn in time and MCMC (Markov Chain Monte Carlo) replication number both to 500,000, and a model for admixture and correlated allele frequencies. Delta $K(\Delta K)$ based on the second order rate of change in the likelihood (Evanno et al., 2005) was used to represent the $\mathrm{K}$ value. Inferred ancestry estimates of individuals (Q-matrix) were derived for the selected subpopulation (Pritchard et al., 2000). Regarding extracted Q values, genotypes with value below 0.7 could not be appointed in distinguished group and so were assigned as mixed genotypes (Spataro et al., 2011). Trait-marker association analysis was performed using mixed linear model (MLM) approach in TASSEL 2.1 (Bradbury et al., 2007) accounting for population structure and kinship relatedness $(\mathrm{Q}+\mathrm{K}$ model $)$. Both kinship coefficients and linkage disequilibrium (LD) were calculated via TASSEL 2.1.

\section{Results}

Polymerase chain reaction assays using 10 ISSR primers amplified 65 ISSR markers on 29 sweet pepper accessions (Table 2). The average number of marker 
Table 2. Characteristics and polymorphism revealed by ISSR primers for 29 sweet pepper accessions used in the study

\begin{tabular}{cccccc}
\hline $\begin{array}{c}\text { ISSR } \\
\text { primer }\end{array}$ & Sequence & $\begin{array}{c}\text { Melting } \\
\text { tempera- } \\
\text { ture } \\
\text { Tm }\end{array}$ & $\begin{array}{c}\text { Total } \\
\text { number } \\
\text { of bands }\end{array}$ & $\begin{array}{c}\text { Poly- } \\
\text { morphic } \\
\text { bands }\end{array}$ & $\begin{array}{c}\text { Percent } \\
\text { of poly- } \\
\text { morphism } \\
\text { detected }\end{array}$ \\
\hline UBC 809 & $(\mathrm{AG})_{8} \mathrm{G}$ & 44 & 10 & 7 & 70 \\
UBC 826 & $(\mathrm{AC})_{8} \mathrm{C}$ & 50 & 7 & 7 & 100 \\
UBC 825 & $(\mathrm{AC})_{8} \mathrm{~T}$ & 51 & 6 & 6 & 100 \\
UBC 817 & $(\mathrm{CA})_{8} \mathrm{~A}$ & 50 & 7 & 7 & 100 \\
UBC 834 & $(\mathrm{AG})_{8} \mathrm{CTT}$ & 44 & 6 & 6 & 100 \\
UBC 812 & $\mathrm{GA})_{8} \mathrm{~A}$ & 48 & 5 & 5 & 100 \\
UBC 811 & $(\mathrm{GA})_{8} \mathrm{C}$ & 42 & 6 & 6 & 100 \\
UBC 827 & $(\mathrm{AC})_{8} \mathrm{G}$ & 48 & 8 & 7 & 87.5 \\
UBC 823 & $(\mathrm{TC})_{8} \mathrm{C}$ & 50 & 7 & 7 & 100 \\
UBC 842 & $(\mathrm{GA})_{8} \mathrm{CTT}$ & 51 & 3 & 2 & 66.6 \\
\hline
\end{tabular}

per primer was 6.5 with the highest number of loci (10) detected by the UBC 809 primer and the smallest number (3) by the UBC 842 primer. Of the 65 amplified markers, $60(92.3 \%)$ were polymorphic. Except for the primers UBC 809 , UBC 827 and UBC842, other primers produced $100 \%$ of polymorphic bands.

In order to elucidate the genetic structure of association panel, a model-based Bayesian approach in the software Structure was used. According to the Evanno et al. (2005) method, $\mathrm{K}=2$ has been recognized as the most likely number of K (Fig. 2A), and 29 sweet pepper accessions were partitioned into two subgroups (Fig. 2B).

The membership percentage of each accession to identified subgroups ( $\mathrm{Q}$ values) is presented in Table 1. Accordingly, most of the samples from East and West Azerbaijan provinces as well as samples from Turkey ('Urfa') located in subgroup (Green) (Table 1, Fig. 3). Also, all of the sweet pepper accessions from Kurdistan province, except for the accession 'Baneh' were located closely in the subgroup (green). Q values revealed that accessions from Lorestan ('Boroujerd') and North Khorasan ('Bojnourd') provinces had mixed genotypic structure (Table 1). Similar to results obtained from Bayesian approach, the cluster analysis based on neighbour-joining algorithm subdivided the studied germplasm into two major subgroups (Fig. 2B).

Paralleled with molecular findings, agrobiological studies of $C$. annuum accessions across two field experiments manifested high genetic variability in sweet pepper association panel. In this regard, average value of most of agrobiological traits show differences among identified subgroups (defined by software Structure analysis) (Fig. 3).

Genotypes in the green subgroup possessed higher values of fruit diameter, number of secondary branches, fresh weight of fruits, dry weight of fruits as well as pericarp thickness compared with genotypes belonging to the red subgroup. Conversely, genotypes in the red subgroup had higher values of plant height, width of inflorescence, fruit length and number of lateral branches. In this project, there was not any difference between the yields of the two subgroups. Interestingly,

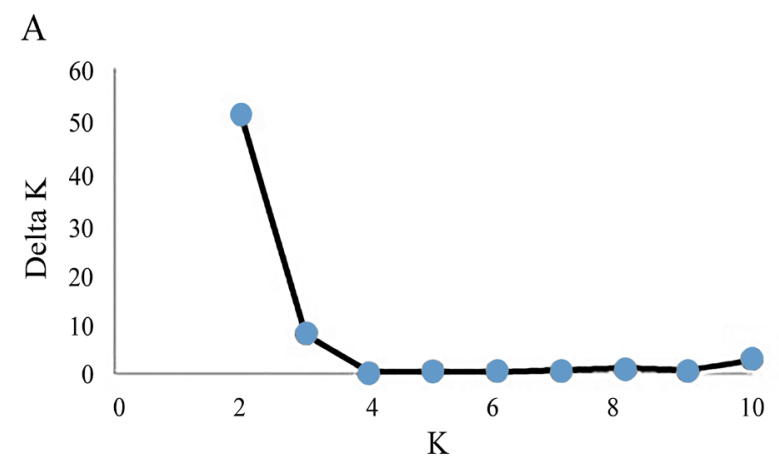

B

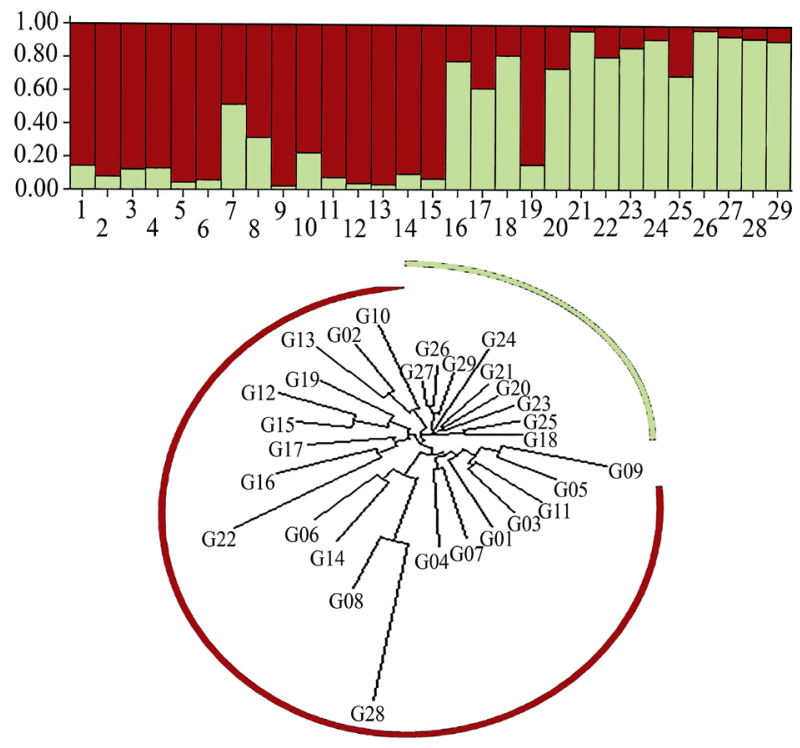

Note. The colour of the bars indicates the two subpopulations identified through the software Structure; the tree was produced using the neighbour-joining UPGMA method based on the 65 ISSR markers.

Figure 2. Determination of optimal number of groups (K value) following the Evanno et al. (2005) method (A), genetic relatedness of 29 sweet pepper accessions based on 65 ISSR markers and phylogenetic tree showing the genetic diversity of the sweet pepper germplasm collection (B)

although genotypes classified in the green subgroup had low fruit length compared to red subgroup, they possessed high level of fruit fresh weight.

In the collection under investigation, $2.3 \%$ of possible ISSR primer pairs showed a significant level of linkage disequilibrium (LD) $(P \leq 0.01)$ (Fig. 4).

The $r^{2}$ values for marker pairs ranged from 0.00 to 0.70 with the average value of 0.06 . MLM procedure based on $\mathrm{Q}+\mathrm{K}$ model was used for identifying markers associated with genes controlling the studied agrobiological characters of sweet pepper accessions (Table 3). A total of 15 markers showed significant association $(P \leq 0.01)$ with QTLs controlling the studied agrobiological traits. For characters including pericarp thickness, fresh weight of 10 fruits, dry weight of 10 fruits, stem diameter, stem length and width of inflorescence only one marker was detected. In our association mapping analysis, 4, 3 and 2 markers were identified for length of flower cup, numbers of secondary and primary branches, respectively. Results pertaining 

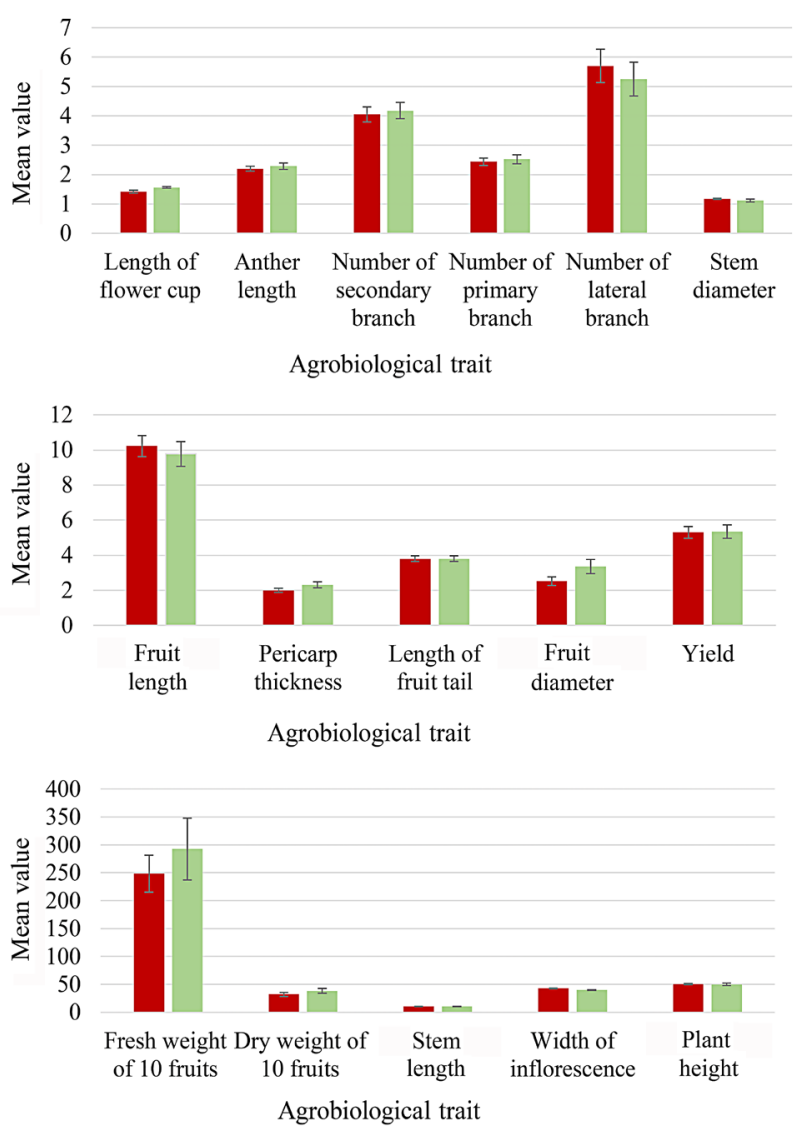

Note. Vertical bars represent the $95 \%$ confidence interval.

Figure 3. Average values of agrobiological traits in the two sweet pepper groups defined by software Structure analysis

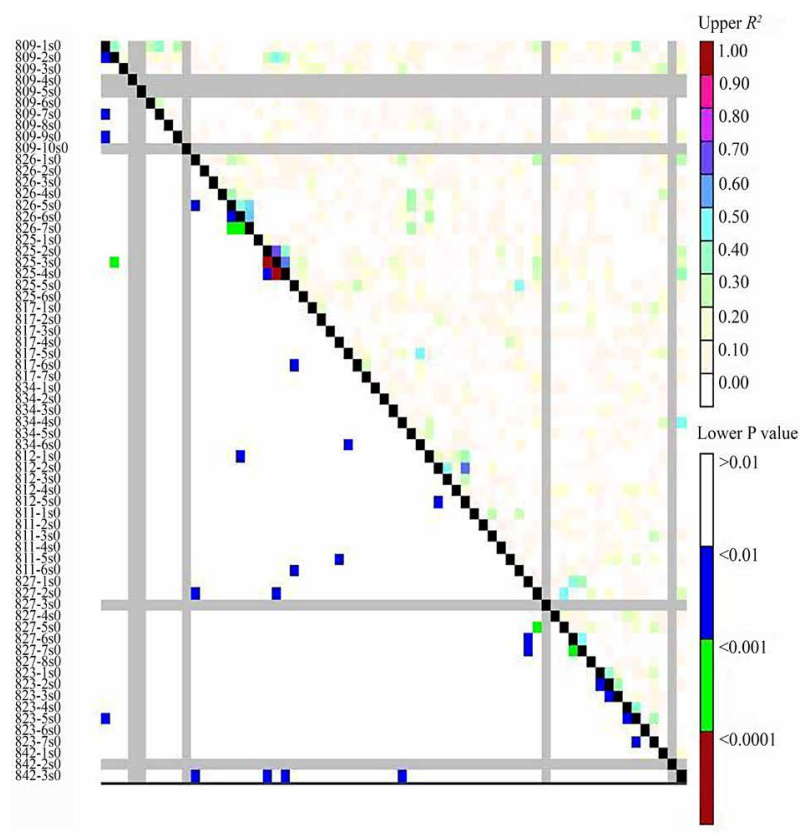

Note. The upper diagonal shows $R^{2}$ among each pair of markers; the lower diagonal shows the levels of significance between each pair of markers.

Figure 4. Linkage disequilibrium (LD) plot generated by ISSR marker pairs in sweet pepper accessions

to association analysis represented co-localized markers for some agrobiological characters. For instance, locus UBC825-4 was associated with pericarp thickness, fresh weight of 10 fruits and dry weight of 10 fruits simultaneously.

Table 3. Inter simple sequence repeat (ISSR) loci identified through mixed linear model as associated with mean of agrobiological traits across two locations

\begin{tabular}{lcllcrcc}
\hline \multicolumn{1}{c}{ Trait } & Locus & $F$ marker & $p$ marker & Trait & Locus & $F$ marker & $p$ marker \\
\hline Pericarp thickness & UBC825-4 & 15.6926 & 0.00 & Length of flower cup & UBC 809-1 & 7.7614 & 0.01 \\
Fresh weight of 10 fruits & UBC 825-4 & 9.0404 & 0.00 & & UBC 825-4 & 7.0613 & 0.01 \\
Dry weight of 10 fruits & UBC 825-4 & 10.5444 & 0.00 & & UBC 809-9 & 7.0322 & 0.01 \\
Yield & UBC 811-4 & 7.0181 & 0.01 & & UBC 823-3 & 6.6747 & 0.01 \\
Stem diameter & UBC 834-3 & 8.4518 & 0.00 & Number of secondary branches UBC 817-5 & 12.6024 & 0.00 \\
Stem length & UBC 834-1 & 10.0397 & 0.00 & & UBC 826-1 6.9979 & 0.01 \\
Width of inflorescence & UBC 826-2 & 9.1776 & 0.00 & & UBC 823-4 6.8005 & 0.01 \\
& UBC 811-6 & 6.42 & 0.01 & Number of primary branches & UBC 827-1 & 13.6635 & 0.00 \\
& & & & & UBC 827-7 8.7295 & 0.00 \\
\hline
\end{tabular}

\section{Discussion}

The present collection of indigenous sweet pepper accessions presented a vast range of genetic variation based on anatomical and molecular characteristics. In agreement with this finding, Zhang et al. (2016) also reported tangible genetic variability within this species. High level of polymorphism was detected by the studied ISSR primers representing vast genetic variation in genomic regions located between simple sequences repeats of $C$. annuum. All of the primers (with the exception of UBC827 and UBC842) can be effectively used in primary evaluation of sweet pepper germplasm. These findings are in line with those reported by Patel et al. (2011) and Thul et al. (2011) regarding the high degree of polymorphism among Capsicum germplasm through ISSR markers. The ISSR markers used in this study distinguished the studied accessions in two subgroups. In this classification, some accessions collected from different provinces such as KashtibanUrmia (West Azerbaijan) and Gachsaran (Kohgiluyeh and Boyer-Ahmad) displayed very close relations. Their similarities may either be caused by close kinship or indicate that they are derivatives from the same cultivar. The admixture observed between the two structure groups demonstrates that introduced genetic material has been exchanged between accessions through breeding and natural recombination. 
Linkage disequilibrium (LD) is defined as the correlation between alleles at different loci in the form of non-random (Laidó et al., 2014). LD provides information about past events and it constrains the potential response to both natural and artificial selection (Gomez et al., 2011). A few studies reported LD patterns in $C$. annuum genome (Nimmakayala et al., 2014; 2016; Taranto et al., 2016). In addition to the vast genetic variability in the studied panel of pepper accessions, significant LD has been also detected which agrees with the findings of Nimmakayala et al. (2014). These identified LD for sweet pepper could be the consequence of self-pollination, low recombination rate and population admixture (Gomez et al., 2011). LD pattern identified for these sweet pepper accessions is useful for successful association analysis through a smaller number of markers.

Molecular markers are proven as selection tools to increase the efficiency of plant breeding activities. Regarding literature review, most of the agrobiological traits of pepper such as plant height, number of fruits per plant, total fruit weight, fruit length, fruit width and pericarp thickness are quantitatively inherited (Barchi et al., 2009; Lu et al., 2012). So, identification of markers linked with such traits makes it possible to do indirect selection by implementing identified DNA markers. Some of the studies have implemented bi-parental populations such as $\mathrm{F}_{3}$ (Ben Chaim et al., 2001), recombinant inbred line (Dwivedi et al., 2015) and $F_{2}$ (Lee et al., 2016) segregating populations for identification of molecular markers linked with genomic region controlling morphological and fruit related characters as well as capsaicin and dihydrocapsaicin in pepper.

However, a few reports were published about association analysis studies in C. annuum. An appropriate germplasm collection with high genotypic and phenotypic diversity for the traits of interest is mandatory for a successful marker-trait analysis through association approach (Gomez et al., 2011). However, the efficiency of association analysis is significantly influenced by the population structure (Ahmadpour et al., 2018). Many statistical models have been used to minimize the false positive errors provoked by the admixture of populations. It has been shown that $\mathrm{K}$ and $\mathrm{Q}$ matrices incorporated into the mixed linear model (MLM) were sufficient to minimize false-positive associations (Zhang et al., 2011).

Our results reveal the efficiency of association analysis in detecting sweet pepper genomic regions conferring agrobiological traits. In this study, one marker (UBC825-1) was common for some of agrobiological traits, albeit specific markers were also found. The common markers between some of the traits can be due to linkage or pleiotropic effects (Basirnia et al., 2014). The common markers are useful in plant improvement program, because they augment the efficiency of marker aided selection through concurrent selection for several characters.

\section{Conclusion}

The present research showed the existence of an overall moderate genetic diversity of sweet pepper accessions in Iran. The study revealed the existence of two separate genetic pools which can be used for widening the genetic base of cultivated sweet peppers. The detected candidate markers and their associated traits will be helpful to improve our knowledge about the genetic architecture of sweet pepper's agrobiological traits and could be applied in the molecular breeding of sweet pepper.

Received 13112018

Accepted 26082019

\section{References}

1. Ahmadpour S., Darvishzadeh R., Sofalian O., Abbaspour N. 2018. Preliminary evidence of the associations between DNA markers and morphological characters in sunflower under natural and salt stress conditions. ZemdirbysteAgriculture, 105 (3): 279-286. https://doi.org/10.13080/z-a.2018.105.036

2. Bagheri G., Zahedi B., Darvishzadeh R., Hajiali A. 2017. Investigation on morphological and physiological variation of some sweet pepper ecotypes (Capsicum annuиm L.). Journal of Horticultural Science, 31: 140-157 (in Persian).

3. Barchi L., Lefebvre V., Sage-Palloix A., Lanteri S., Palloix A. 2009. QTL analysis of plant development and fruit traits in pepper and performance of selective phenotyping. Theoretical and Applied Genetics, 118: $1157-1171$.

https://doi.org/10.1007/s00122-009-0970-0

4. Basirnia A., Hatami Maleki H., Darvishzadeh R., Ghavami F. 2014. Mixed linear model association mapping for low chloride accumulation rate in oriental-type tobacco (Nicotiana tabaccum L.) germplasm. Journal of Plant Interactions, 9: 666-672.

https://doi.org/10.1080/17429145.2014.893453

5. Ben Chaim A., Paran I., Grube R. C., Jahn M., Van Wijk R., Peleman J. 2001. QTL mapping of fruit-related traits in pepper (Capsicum annuum). Theoretical and Applied Genetics, 102: 1016-1028.

https://doi.org/10.1007/s001220000461

6. Bradbury P. J., Zhang Z., Kroon D. E., Casstevens T. M., Ramdoss Y., Buckler E. S. 2007. TASSEL: software for association mapping of complex traits in diverse samples. Bioinformatics, 23 (19): 2633-2635. https://doi.org/10.1093/bioinformatics/btm308

7. Devi K. D., Punyarani K., Singh N. S., Devi H. S. 2013. An efficient protocol for total DNA extraction from the members of order Zingiberales-suitable for diverse PCR based downstream applications. SpringerPlus, 2: 669. https://doi.org/10.1186/2193-1801-2-669

8. Dias G. B., Gomes V. M., Moraes T. M. S., Zottich U. P., Rabelo G. R., Carvalho A. O., Moulin M., Gonçalves L. S. A., Rodrigues R,. Da Cunha M. 2013. Characterization of Capsicum species using anatomical and molecular data. Genetics and Molecular Research, 12: 6488-6501.

https://doi.org/10.4238/2013.February.28.29

9. dos Santos Araújo F., Pacheco M. V., de Almeida Vieira F., dos Santos Ferrari C., Félix F. C., das Chagas K. P. T. 2016. ISSR molecular markers for the study of the genetic diversity of Mimosa caesalpiniaefolia Benth. Idesia, 34 (3): 47-52.

https://doi.org/10.4067/S0718-34292016000300007

10. Dwivedi N., Kumar R., Paliwal R., Kumar U., Kumar S., Singh M., Kumar Singh R. 2015. QTL mapping for important horticultural traits in pepper (Capsicum annum L.). Journal of Plant Biochemistry and Biotechnology, 24 (2): 154-160. https://doi.org/10.1007/s13562-013-0247-1 
11. Evanno G., Regnaut S., Goudet J. 2005. Detecting the number of clusters of individuals using the software Structure: a simulation study. Molecular Ecology, 14: 26112620. https://doi.org/10.1111/j.1365-294X.2005.02553.x

12. Gomez G., Alvarez M. F., Mosquera T. 2011. Association mapping, a method to detect quantitative trait loci: statistical bases. Agronomia Colombiana, 29: 367-376.

13. Hodgkin T., Bordoni P. 2012. Climate change and the conservation of plant genetic resources. Journal of Crop Improvement, 26: 329-345.

https://doi.org/10.1080/15427528.2011.609928

14. Isshiki S., Iwata N., Khan M. M. R. 2008. ISSR variations in eggplant (Solanum melongena L.) and related Solanum species. Scientia Horticulturae, 117: 186-190. https://doi.org/10.1016/j.scienta.2008.04.003

15. Korte A., Farlow A. 2013. The advantages and limitations of trait analysis with GWAS: a review. Plant Methods, 9: 29. https://doi.org/10.1186/1746-4811-9-29

16. Kumar A., Mishra P., Singh S. C., Sundaresan V. 2014. Efficiency of ISSR and RAPD markers in genetic divergence analysis and conservation management of Justicia adhatoda L., a medicinal plant. Plant Systematics and Evolution, 300: 1409-1420. https://doi.org/10.1007/s00606-013-0970-z

17. Laidó G., Marone D., Russo M. A., Colecchia S. A., Mastrangelo A. M., De Vita P., Papa R. 2014. Linkage disequilibrium and genome-wide association mapping in tetraploid wheat (Triticum turgidum L.). PLoS ONE, 9: e95211. https://doi.org/10.1371/journal.pone.0095211

18. Lee J., Park S. J., Hong S. C., Han J. H., Choi D., Yoon J. B. 2016. QTL mapping for capsaicin and dihydrocapsaicin content in a population of Capsicum annuum 'NB1' $\times$ Capsicum chinense 'Bhut Jolokia'. Plant Breeding, 135 (3): 376-383. https://doi.org/10.1111/pbr.12355

19. Lu F. H., Kwon S. W., Yoon M. Y., Kim K. T., Cho M. C., Yoon M. K., Park Y. J. 2012. SNP marker integration and QTL analysis of 12 agronomic and morphological traits in $\mathrm{F}_{8}$ RILs of pepper (Capsicum annuum L.). Molecular Cells, 34: 25-34.

https://doi.org/10.1007/s10059-012-0018-1

20. Myles S., Peiffer J., Brown P. J., Ersoz E. S., Zhang Z., Costich D. E., Buckler E. S. 2009. Association mapping: critical considerations shift from genotyping to experimental design. The Plant Cell, 21: 2194-2202. https://doi.org/10.1105/tpc.109.068437

21. Nimmakayala P., Abburi V. L., Abburi L., Alaparthi S. B., Cantrell R., Park M., Choi D., Hankins G., Malkaram S., Reddy U. K. 2014. Linkage disequilibrium and population structure analysis among Capsicum annuum L. cultivars for use in association mapping. Molecular Genetics and Genomics, 289: 513-521.

https://doi.org/10.1007/s00438-014-0827-3

22. Nimmakayala P., Abburi V. L., Saminathan T., Alaparthi S. B., Almeida A., Davenport B., Nadimi M., Davidson J., Tonapi K., Yadav L., Malkaram S., Vajja G., Hankins G., Harris R., Park M., Choi D., Stommel J., Reddy U. K.. 2016. Genome-wide diversity and association mapping for capsaicinoids and fruit weight in Capsicum annuиm L. Scientific Reports, 6: 38081. https://doi.org/10.1038/srep38081

23. Padilha H. K. M., Barbieri R. L. 2016. Plant breeding of chili peppers (Capsicum, Solanaceae) - a review. Australian Journal of Basic and Applied Sciences, 10: 148-154.
24. Patel A. S., Sasidharan N., Ashish G. V., Vinay K. 2011. Genetic relation in Capsicum annuum cultivars through microsatellite markers: SSR and ISSR. Electronic Journal of Plant Breeding, 2: 67-76.

25. Pozzobon M. T., Schifino-Wittmann M. T., Bianchetti L. D. B. 2005. Chromosome numbers in wild and semi domesticated Brazilian Capsicum L. (Solanaceae) species: do $\mathrm{x}=12$ and $\mathrm{x}=13$ represent two evolutionary lines? Botanical Journal of the Linnean Society Banner, 151: 259-269. https://doi.org/10.1111/j.1095-8339.2006.00503.x

26. Pritchard J. K., Stephanes M., Rosenberg N. A., Donnelly P. 2000. Association mapping in structured populations. American Journal of Human Genetics, 67: 170-181. https://doi.org/10.1086/302959

27. Spataro G., Tiranti B., Arcaleni P., Bellucci E. 2011. Genetic diversity and structure of a worldwide collection of Phaseolus coccineus L. Theoretical and Applied Genetics, 122: 1281-1291.

https://doi.org/10.1007/s00122-011-1530-y

28. Taranto F., D’Agostino N., Greco B., Cardi T., Tripodi P. 2016. Genome-wide SNP discovery and population structure analysis in pepper (Capsicum annuum) using genotyping by sequencing. BMC Genomics, 17: 943. https://doi.org/10.1186/s12864-016-3297-7

29. Thul S. T., Darokar M. P., Shasany A. K., Khanuja S. P. S. 2011. Molecular profiling for genetic variability in Capsicum species based on ISSR and RAPD markers. Molecular Biotechnology, 51: 137-147. https://doi.org/10.1007/s12033-011-9446-y

30. van Zonneveld M., Ramirez M., Williams D. E., Petz M., Meckelmann S., Avila T., Bejarano C., Ríos L., Peña K., Jäger M., Libreros D., Amaya K., Scheldeman X. 2015. Screening genetic resources of Capsicum peppers in their primary center of diversity in Bolivia and Peru. PLoS ONE, 10 (9): e0134663.

https://doi.org/10.1371/journal.pone.0134663

31. Verdeprado H., Kretzschmar T., Begum H., Raghavan C., Joyce P., Lakshmanan P., Cobb J. N., Collard B. C. Y. 2018. Association mapping in rice: basic concepts and perspectives for molecular breeding. Plant Production Science, 21: 159-176. https://doi.org/10.1080/1343943X.2018.1483205

32. Zhang J., Hao C., Ren Q., Chang X., Liu G., Jing R. 2011. Association mapping of dynamic developmental plant height in common wheat. Planta, 234: 891-902. https://doi.org/10.1007/s00425-011-1434-8

33. Zhang X., Zhang Z., Gu X., Mao S., Li X., Joël C., Alain P., Wang L., Zhang B. 2016. Genetic diversity of pepper (Capsicum spp.) germplasm resources in China reflects selection for cultivar types and spatial distribution. Journal of Integrated Agriculture, 15: 1991-2001. https://doi.org/10.1016/S2095-3119(16)61364-3 
ISSN 1392-3196 / e-ISSN 2335-8947

Zemdirbyste-Agriculture, vol. 106, No. 4 (2019), p. 337-344

DOI 10.13080/z-a.2019.106.043

\title{
Molekulinių žymeklių, susijusių su Capsicum annuum genotipų agrobiologiniais požymiais, genetinè struktūra ir identifikavimas
}

\author{
H. Hatami Maleki ${ }^{1}$, R. Darvishzadeh ${ }^{2}$, M. Salehian ${ }^{2}$, G. Bagheri $^{3}$, B. Zahedi ${ }^{3}$ \\ ${ }^{1}$ Maragheh universiteto Žemès ūkio fakultetas, Iranas \\ ${ }^{2}$ Urmia universiteto Žemès ūkio fakultetas, Iranas \\ ${ }^{3}$ Lorestan universiteto Žemès ūkio fakultetas, Iranas
}

\section{Santrauka}

Saldžioji paprika (Capsicum annuum L.) yra laikoma viena svarbiausių daržovių pasaulyje. Asociacijų žemėlapiai, pagrịsti sąsajų nestabilumu, yra tinkama priemonè nustatyti genus, kontroliuojančius augalų agrobiologines savybes.

Tyrimo metu iš keleto Irano geografinių regionų buvo surinkta asociacijų grupé, kurią sudarè 29 vietiniai saldžiosios paprikos genotipai. Dviejose vietovėse lauko sąlygomis fenotipiškai buvo tirta šių genotipu 16 vaisių ir augalų architektūros požymių. Genotipavimui buvo panaudota 10 kartotinių paprastų sekų intarpų (ISSR) žymeklių. Tyrimo rezultatai atskleide šios genetinès medžiagos fenotipinę variaciją: visuose genotipuose iš viso buvo nustatyti 65 žymekliai, nuo 3 iki 10 vienam pradmeniui. Modelio pagrindu atlikus struktūrinę analizę nustatytos dvi subpopuliacijos. Iš 29 tirtų vietinių saldžiosios paprikos genotipų 93,1 \% priklausè vienai iš dviejų nustatytų subpopuliacijų, o 6,9 \% buvo mišrios struktūros. Remiantis mišriu linijiniu modeliu, iš viso buvo nustatyta 17 žymeklių ir požymių asociacijų, iš kurių viena (UBC825-1) įvardyta kaip bendras kelių agrobiologinių savybių žymeklis. Nustatyti 17 žymeklių lokusai gali būti naudojami augalų architektūros selekcinèse programose siekiant konkrečių selekcijos tikslų.

Reikšminiai žodžiai: mišrus linijinis modelis, saldžioji paprika, sąsajos nestabilumas, žymeklių ir požymių asociacija. 